\title{
Procalcitonin as a Marker of the Systemic Inflammatory Response to Infection on Newborn and Children (up to 1 year)
}

\author{
GABRIEL ILYES ${ }^{1,2 *}$, NARCISA CARMEN MLADIN ${ }^{3 *}$, MARIUS CRAINA ${ }^{1}$, IZABELLA PETRE$^{1}$, NICOLAE SUCIU4*, ANCA TUDOR ${ }^{5}$, \\ ROXANA OANCEA ${ }^{6 *}, B^{\circ} O G D A N$ ANDOR ${ }^{7 \#, ~ D A N I E L A ~ R A D U 8 ~}$ \\ ${ }^{1}$ Victor Babes University of Medicine and Pharmacy, Department XII, Discipline of Obstetrics and Gynecology, 2 Eftimie Murgu \\ Sq., 300041,Timisoara, Romania \\ ${ }^{2} \mathrm{SC}$ dr. Ilyes Stelian SRL, Arad, Romania \\ 3. Vasile Goldis West University of Arad, Faculty of Medicine, Department of General Medicine, 94 Revolutiei Blvd.,310025, Arad, \\ Romania \\ ${ }^{4}$ Carol Davila University of Medicine and Pharmacy, Department of Obstetrics and Gynecology, Alessandrescu Rusescu Institute \\ for Mother and Child Care, Bucharest,120 Lacul Tei Blvd., 020395, Romania \\ ${ }^{5}$ Victor Babes University of Medicine and Pharmacy, Department of Functional Sciences,Medical Informatics and Biostatistics \\ Discipline, 2 Eftimie Murgu Sq., 300041 Timisoara, Romania \\ Victor Babes University of Medicine and Pharmacy, Faculty of Dental Medicine, Department I, 2 Eftimie Murgu Sq., 300041, \\ Timisoara, Romania \\ TVictor Babes University of Medicine and Pharmacy, Department XVof Orthopedics, Traumatology, Urology and Imaging, 2 \\ Eftimie Murgu Sq., 300041, Timisoara, Romania \\ ${ }^{8}$ Victor Babes University of Medicine and Pharmacy, Surgery Department, 2 Eftimie Murgu Sq., 300041, Timisoara, Romania
}

\begin{abstract}
In the lastyears, procalcitonin (PCT) has been proposed as an early marker ofinfections in newborns having registered different results. In this study, we aimed to investigate the value of serum procalcitonin for the diagnosis of sepsis in neonates and children procalcitonin in the diagnosis of neonatal sepsis and in children up to 1 year in the pathology of therespiratory system, gastrointestinal pathology, etc. At first, we established the clinical and paraclinical signs of systemic inflammation: increasing the temperature of the system, tachycardia, laboratory test: leukocytosis, C-reactive protein - for the diagnosis of sepsis.Some studies show that PCT gave a sensitivity between $83-100 \%$ and a specificity between $70-100 \%$ in early diagnosis of neonatal sepsis [1-7]; other researches question the accuracy of PCT in detecting neonatal sepsis.Procalcitonin (PCT) has been proposed as a marker of bacterial sepsis in critically ill patients. PCT is a precursor of calcitonin and a 116 amino acids protein. PCT levels more than $0.5 \mathrm{mg} / \mathrm{dl}$ are useful to determine the type of infectious process (bacterial or not).
\end{abstract}

Keywords: PCT, procalcitonin, newborns, childrens

Biomarkers are becoming more and more important in the early diagnosis of infectious disease. The characteristics of an ideal biomarker include excellent sensitivity and negative predictive value as well as excellent specificity and positive predictive value [8-9].

Biomarker levels that are found modified at the disease onset and afterwards could provide physicians the opportunity to correlate the results of the biomarker analyses in order to optimize clinical management, monitor disease progression, and guide anti-infective treatment [1013].

Numerous studies and research in the field trying to elucidate the immune system of the newborn. In the past decade, more and more studies have been focused on this immune complex identifying and using various biomarkers having great potential for early diagnosis of sepsis and the pathology associated with pregnancy [14-19].

The level of procalcitonin reflects the degree of systemic inflammatory response [20-24].

Bacterial endotoxins have a crucial role in the process of inducing this protein; Procalcitonin levels closely correlate with the severity and spread of the infection.
Other factors that influence the level of procalcitonin are: the type and size of the infected organ, the bacterial species, the degree of inflammation and the immune reactivity of the body. PCT becomes measurable within 2-4 hours of the trigger event, reaching maximum levels after 12-24 hours [25-30].

With the increase in the incidence of obesity worldwide, DZ prevalence predisposes some women to gestational diabetes. The association between DZ and pregnancy can seriously affect the health of the mother and the future fetus (congenital malformations). Although maternal death is unusual, it may occur in association with other pathologies associated with pregnancy (preeclampsia, renal disease, ketoacidosis, HTAIS) [31-38].

\section{Experimental part}

Material and method

Our sample contains 134 subjects ( 67 newborns and 67 children). We considered the main diagnosis and the results of the PCT intervals. Diagnosis at admission was divided into three categories: abdominal pathology, respiratory and other pathologies. The PCT intervals have 
been considered from the literature of speciality. The data was processed using SPSS v17 statistical package and Microsoft Excel software. The nominal data were compared with Chi-Square Test and the associations between these categorial series were achieved also with Chi2 Test.

The Odds Ratio (OR) and the confidence interval for OR were calculated by risk analysis. For $O R>1$ and if the confidence interval for $O R$ does not contain 1 , the risk factor is considered to exist. For $p<0.05$ were considered statistical significance.

\section{Results and discussions}

Between the PCT reference intervals and the associated pathology, a significant association was determined (Chisquare Test, $p<0.001$ ) (table 1).

By comparing the percentages for each PCT reference interval between abdominal and respiratory pathology (Chisquare Test) we obtained statistical differences as follows:

- for normal PCT values, the abdominal percentage was significant greater than the respiratory percentage, which is equivalent to the fact that the percentage of children with pathological PCT values is significantly increased in the case of respiratory pathology compared to the abdominal $(p=0.029)$.

-for $[0.5,2) \mathrm{ng} / \mathrm{mL}$ reference values were found insignificant differences $(p=0.891)$

-for $(2,10) \mathrm{ng} / \mathrm{mL}$ reference values were found insignificant differences $(p=0.387)$

-for PCT values greater then 10, the abdominal percentage was insignificant lower than the respiratory percentage $(p=0.173)$ (fig.2).

Respiratory pathology is a risk factor for increasing PCT values (Odds Ratio $=6.09$ with the confidence interval [1.27; 29.29] and with a 87\% specificity) (table 2).

No significant differences were found between the proportions of newborns and children by PCT reference intervals groups (Chi-square Test. $p=0.194$ ).

We plotted the comparison between children and newborns for the PCT values (fig. 3).

Table 1

\begin{tabular}{|c|c|c|c|c|c|}
\hline \multirow{2}{*}{ Pathology } & \multicolumn{4}{|c|}{ PCT reference interval } & \multirow{2}{*}{$\begin{array}{l}\text { Total } \\
\text { cases }\end{array}$} \\
\hline & $<0.5 \mathrm{ng} / \mathrm{mL}$ & {$[0.5 .2) \mathrm{ng} / \mathrm{mL}$} & [2.10) $\mathrm{ng} / \mathrm{mL}$ & $\geq 10 \mathrm{ng} / \mathrm{mL}$ & \\
\hline \multirow{2}{*}{ Abdominal } & 13 & 1 & 0 & 1 & 15 \\
\hline & $86.67 \%$ & $6.67 \%$ & $0.00 \%$ & $6.67 \%$ & $100.0 \%$ \\
\hline \multirow{2}{*}{ Others } & 19 & 13 & 12 & 13 & 57 \\
\hline & $33.33 \%$ & $22.81 \%$ & $21.05 \%$ & $22.81 \%$ & $100.0 \%$ \\
\hline \multirow{2}{*}{ Respiratory } & 32 & 6 & 7 & 17 & 62 \\
\hline & $51.61 \%$ & $9.68 \%$ & $11.29 \%$ & $27.42 \%$ & $100.0 \%$ \\
\hline
\end{tabular}

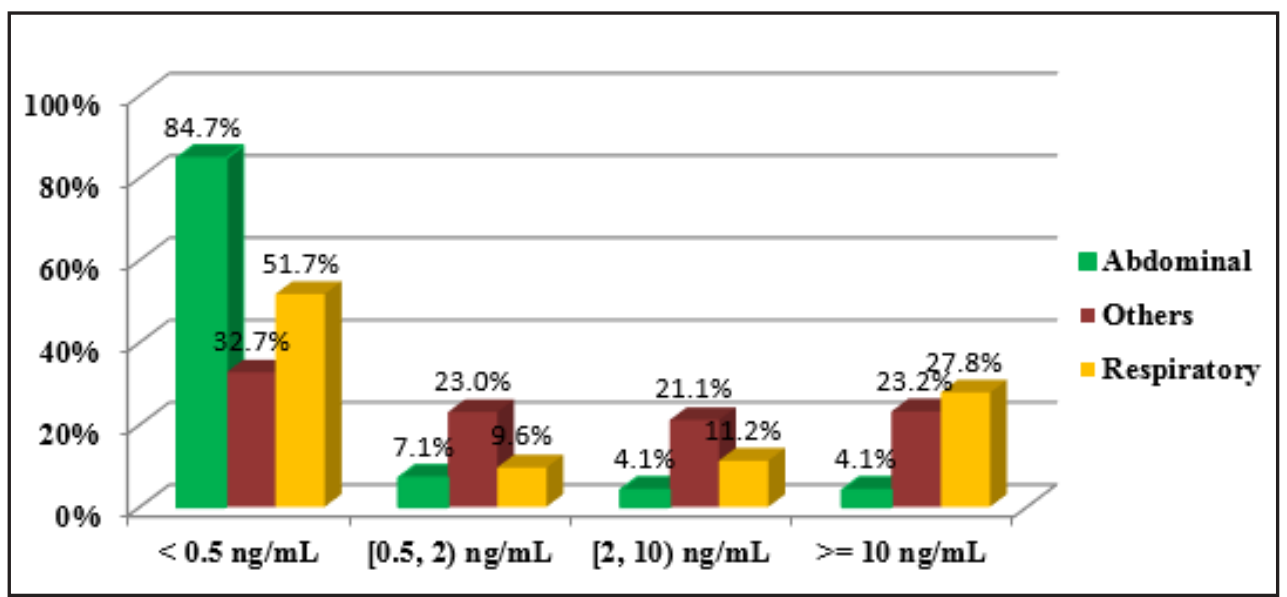

Fig. 1. Percentage distribution of cases by pathology and PCT reference range

Table 2

COMPARISON BETWEEN CHILDREN AND NEWBORNS.

\begin{tabular}{|c|c|c|c|c|c|}
\hline Case & $<\mathbf{0 . 5} \mathbf{~ n g} / \mathbf{m L}$ & {$[\mathbf{0 . 5 . 2}) \mathbf{n g} / \mathbf{m L}$} & {$[\mathbf{2 . 1 0} \mathbf{n g} / \mathbf{m L}$} & $>=\mathbf{1 0} \mathbf{~ n g} / \mathbf{m L}$ & Total \\
\hline \multirow{2}{*}{ newborns } & 34 & 13 & 9 & 11 & 67 \\
\cline { 2 - 6 } & $50.7 \%$ & $19.4 \%$ & $13.4 \%$ & $16.4 \%$ & $100.0 \%$ \\
\hline \multirow{2}{*}{ children } & 30 & 7 & 10 & 20 & 67 \\
\cline { 2 - 6 } & $44.8 \%$ & $10.4 \%$ & $14.9 \%$ & $29.9 \%$ & $100.0 \%$ \\
\hline
\end{tabular}




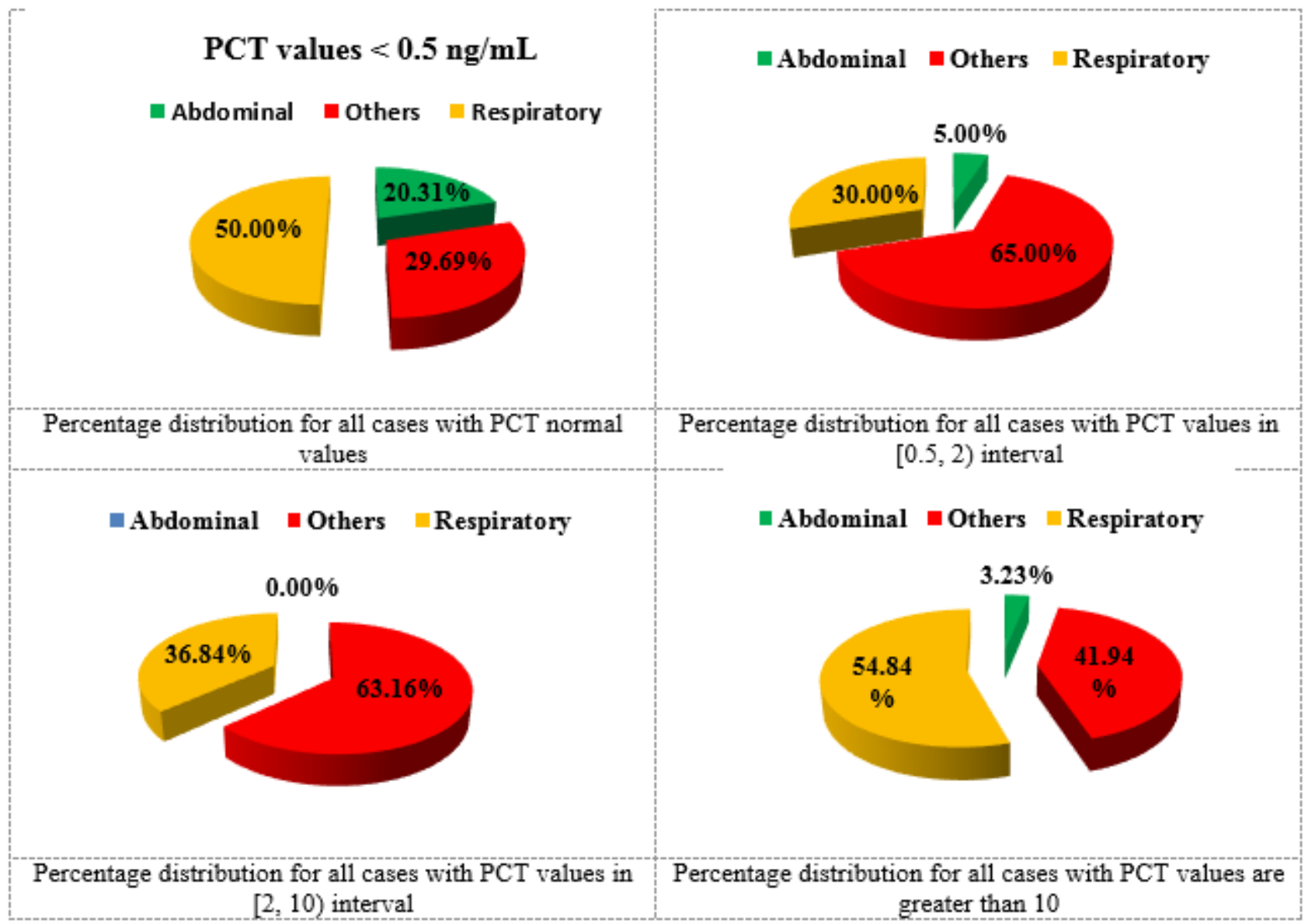

Fig. 2. We plotted the percentage distribution for the PCT values

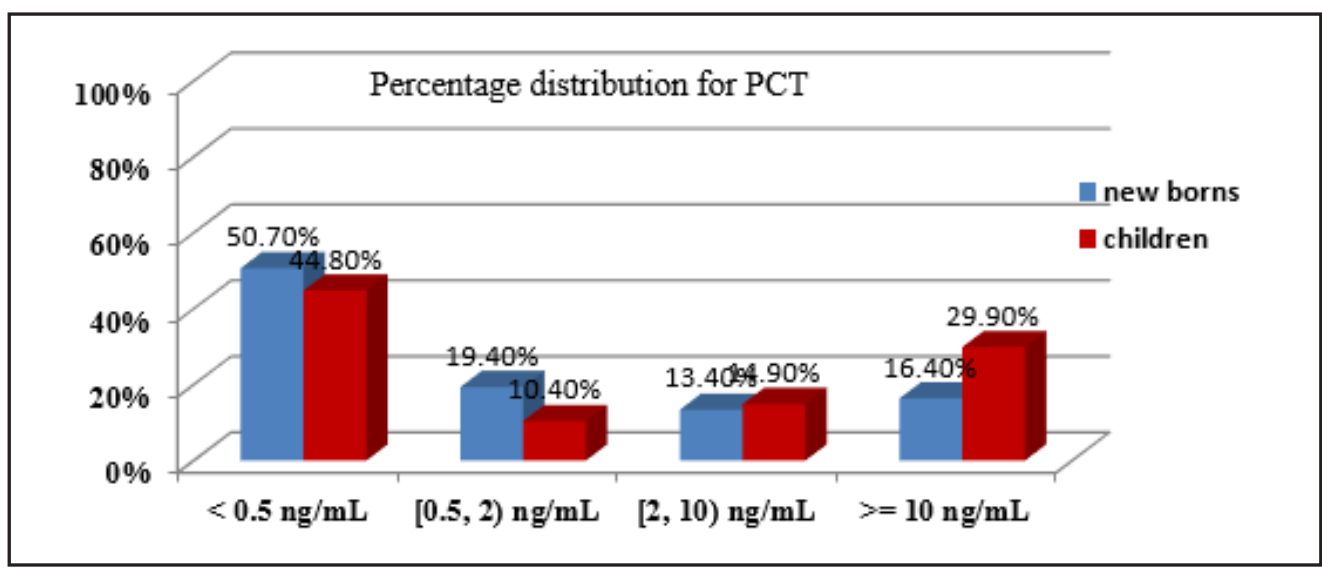

Fig. 3. The comparison between children and newborns for the PCT values

\section{Conclusions}

Regarding the newborn. the immune function is dependent on the gestational age at which birth has been occurred. resulting in increased susceptibility to infection leading to an increased risk of morbidity and mortality due to sepsis.

\section{References}

1.MARTIN GS., MANNINO DM., EATON S., MOSS M., The epidemiology of sepsis in the United States from 1979 through 2000. N Engl J Med 2003; 348:1546-54.

2.ANGUS D.C., LINDE-ZWIRBLE W.T., LIDICKER J., CLERMONT G., CARCILLO J., PINSKY M.R., Epidemiology of severe sepsis in the United States: analysis of incidence. outcome. and associated costs of care. Crit Care Med 2001; 29:1303-10.
3.WHICHER J ., BIENVENU J., MONNERET G., Procalcitonin as an acute phase marker. Ann Clin Biochem 2001; 38:483-93

4.MITAKA C., Clinical laboratory differentiation of infectious versus noninfectious systemic inflammatory response syndrome. Clin Chim Acta. 2005;351:17-29.

5.MEISNER M.,Pathobiochemistry and clinical use of procalcitonin. Clin Chim Acta. 2002;323:17-29

6.BECKER K.L., SNIDER R., NYLEN E.S., Procalcitonin assay in systemic inflammation. infection. and sepsis: Clinical utility and limitations. Crit Care Med. 2008;36:941-52.

7.CHUA A.P., LEE K.H., Procalcitonin in severe acute respiratory syndrome (SARS) J Infect. 2004;48:303 
8.MLADIN-MICOARA, N.C., LUNGEANU, D., MORARIU, S.I., CIACLI, C.A., MOLERIU, L.C., STELEA, L.,PETRE, I., IONITA, I., CALAMARPOPOVICI, D.,Puschita M.Biomarkers in Diagnosing Preeclampsia and their Correlation with Blood Pressure. Rev. Chim. (Bucharest), 68, no. 10, 2017, p. $2449-2501$

9.MOZA A., BRISAN L., BURLICA S.,PETRE I., NYIREDI A.,The Management of Pregnancy with Antepartum Fetal Death.The 13th Conference of the Romanian-German Society of Obstetrics and Gynecology.Timi-oara. Romania. 14-16 September 2017. pag 515 -519. Ed. Filodiritto Editore

10.CHRISTENSEN R.D., BAER V.L., GORDON P.V., et al., Reference ranges for lymphocyte counts of neonates: associations between abnormal counts and outcomes. Pediatrics. 2012;129(5):e1165-e1172 11.CHIESA C., NATALE F., PASCONE R., et al., C reactive protein and procalcitonin: reference intervals for preterm and term newborns during the earlyneonatal period. Clin Chim Acta. 2011;412(11-12):10531059

12.NG P.C., LAM H.S., Biomarkers for late-onset neonatal sepsis: cytokines and beyond. Clin Perinatol. 2010;37(3):599-610

13.LAM H.S., NG P.C., Biochemical markers of neonatal sepsis. Pathology. 2008;40(2):141-148

14.POLIN R.A., RANDIS T.M., Biomarkers for late-onset neonatal sepsis. Genome Med. 2010;2(9):58

15.KHAIR K.B., RAHMAN M.A., SULTANA T., ROY C.K., RAHMAN M.Q., AHMED A.N., Early diagnosis of neonatal septicemia by hematologic scoring system. C-reactive protein and serum haptoglobin. MymensinghMedJ . 2012;21(1):85-92.

16.RESCH B., GUSENLEITNER W., MULLER W., Procalcitonin. interleukin-6. C-reactive protein and leukocyte counts in infants with bronchiolitis. Pediatr Infect Dis J. 2003;22(5):475-476

17.ENGUIX A., REY C., CONCHA A., MEDINA A., COTO D., DIEGUEZ M.A., Comparison of procalcitonin with C-reactive protein and serum amyloid for the early diagnosis of bacterial sepsis in critically ill neonates and children. Intensive Care Med. 2001;27(1):211-215.

18.SIMON L., SAINT-LOUIS P., AMRE D.K., LACROIX J., GAUVIN F., Procalcitonin and C-reactive protein as markers of bacterial infection in critically ill children at onset of systemic inflammatory response syndrome. Pediatr Crit Care Med. 2008;9(4):407-413

19.KORDEK A., HAfASA M., PODRAZA W., Early detection of an early onset infection in the neonate based on measurements of procalcitonin and C-reactive protein concentrations in cord blood. Clin Chem Lab Med. 2008;46(8):1143-1148.

20.MILULESCU, A., DORNEANU, F., IACOB, D., STOIAN, D., PETRE, I., CHIRIA, V.D., MARGAN, R., IONITA, I., MARTI, D., MOLERIU,, L.C.,Procalcitonina - Diagnostic Marker in Neonatal Sepsis, Mat. Plast., 54, no. 4. 2017, p.752-753

21.PETRE I., CRAINA M., BERNAD E., MOZA A., IACOB D., CHIRIAC V.D., BOGLUT A., BACEAN MILOICOV O.C., MOLERIU L.C., The Management of Threat in Preterm Birth of Patients with Singleton Pregnancy The 13th Conference of the Romanian-German Society of Obstetrics and Gynecology. Timi-oara. Romania. 14-16 September 2017. pg 227 - 231. Ed. Filodiritto Editore Proceeding. ISBN 978-8895922-95-9

22.PETRE I., CRAINA M., BERNAD E., DORNEANU F., CITU I., CITU C., STELEA L., IACOB D., BOGLUT A., MOLERIU R.D.,Procalcitonin Neonatal Sepsis Biomarker. The 13th Conference of the RomanianGerman Society of Obstetrics and Gynecology. Romania.2017. pg 232 $-236$.

23.DIMA, M., IACOB, D., DUTA, C., PANTEA, S., MARGINEAN, O., BERNAD, E., CRAINA, M., BOGLUT, A., PETRE I.,Association Between Mannose - binding Lectin and Serum Parameters of Neonatal Sepsis. Rev .Chim.(Bucharest), 67, no 3, 2016, p.557 -560.
24.BONTE, D.C., BOGLUT, A., DUTA, C., PETRE, I., BERNAD, E., DALIBORCA, C.V., IACOB, R.E., DIMA, M., IACOB, D.,The Harmful Effects of Smoking during Pregnancy and Correlating Lead and Selenium Levels in Mothers and Premature Fetuses.Rev .Chim.(Bucharest), 67, no 1, 2016, p. 116-118

25.LUZZANI A., POLATI E., DORIZZI R., RUNGATSCHER A., PAVAN R., MERLINI A., Comparison of procalcitonin and C-reactive protein as markers of sepsis. Critical Care Medicine. 2003;31(6):1737-1741

26.CHIESA C., PANERO A., ROSSI N., et al., Reliability of procalcitonin concentrations for the diagnosis of sepsis in critically ill neonates. Clin Infect Dis. 1998;26(3):664-672.

27.WHICHER J., BIENVENU J., MONNERET G., Procalcitonin as an acute phase marker. Ann Clin Biochem. 2001;38(Pt 5):483-493

28.PAVCNIK-ARNOL M., HOJ KER S., DERGANC M., Lipopolysaccharidebinding protein in critically ill neonates and children with suspected infection: comparison with procalcitonin. interleukin-6. and C-reactive protein. Intensive Care Med. 2004;30(7):1454-1460

29.Van ROSSUM A.M.C., WULKAN R.W., OUDESLUYS-MURPHY A.M., Procalcitonin as an early marker of infection in neonates and children. Lancet InfectDis. 2004;4(10):620-630

30.TURNER D., HAMMERMAN C., RUDENSKY B., SCHLESINGER Y., GOIA C., SCHIMMEL M.S., Procalcitonin in preterm infants during the first few days of life: introducing an age related nomogram. Arch Dis Child Fetal Neonatal Ed. 2006;91(4):F283-F286

31.IVAN M.V., ZALA A., AGOP A., PUIU E., VAIDEANU D., PALAMACIUC I., IANCU D.T., CRISAN-DABIJA R., Several aspects about fractality role in the dynamics of complex systems. ISSN 1223-7027 Revista UPB. vol 79. pg 235-246. mar 2017

32.TURNER D., HAMMERMAN C., RUDENSKY B., SCHLESINGER Y., GOIA C., SCHIMMEL M.S.,Procalcitonin in preterm infants during the first few days of life: introducing an age related nomogram. Arch Dis Child Fetal Neonatal Ed. 2006;91(4):F283-F286

33.MUNTEANU, M., APOSTOL, A., IVAN, V., New Considerations Regarding Chronic Kidney Disease. Cardiovascular Disease and Dyslipidemia in Diabetic Patients Rev .Chim.(Bucharest), 69, no. 8, 2018, p.2064-2066

34.GADALEAN F., SIMU M., PARV F., VOROVENCI R., TUDOR R., SCHILLER A., TIMAR R., PETRICA L., VELCIOV S., GLUHOVSCHI C., BOB F., MIHAESCU A., TIMAR B., SPASOVSKI G., IVAN V., The impact of acute kidney injury on in-hospital mortality in acute ischemic stroke patients undergoing intravenous thrombolysis. PLOS ONE Volume:12 Issuue:10 Article number:e0185589 Published:OCT 172017

35.ANDOR B., DANCIU C., ALEXA E., ZUPKO I., HOGEA E., CIOCA A., CORICOVAC D., PINZARU I., PATRASCU J., MIOC M., CRISTINA R. T., SOICA C., DEHELEAN C., Germinated and ungerminated seeds extract from two Lupinus Species: Biological Compounds Characterization and in vitro and in vivo evaluations Evidence-Based Complementary and Alternative Medicine Article ID 7638542. 2016. p. 1-8

36.ALBAI A., SIMA A., PAPAVA I., ROMAN D., ANDOR B., GAFENCU M., Associations betw een coping mechanisms and adherence to diabetes related self-care activities: a cross-sectional study. Patient preference and adherence Volume 11. 2017. p. 1235-1241

37. IVAN M.V., ROGOBETE A., BEDREAG O. et al. -New Molecular and EpigenicExpression as Novel Biomarkers in Critically III Polytrauma Patients with Acute Kidney Injury (AKI) -Clinical Laboratory, volume:64 Issue:5, pg 663-668.

38.ROGOBETE A.F., SANDESC D., BEDREAG O.H., PAPURICA M., POPOVICI S.E., BRATU T., POPOIU C.M., NITU R., DRAGOMIR T., AABED H., IVAN M.V. - MicroRNA Expression is Associated with Sepsis Disorders in Critically III Polytrauma Patients. Cells. 2018;7(12):271. Published 2018 Dec 13.

$\overline{\text { Manuscript received } 27.08 .2018}$ 